\title{
Structure, market power, and profitability: evidence from the banking sector in Latin America
}

\author{
Cristiano Hordones ${ }^{1}$ \\ (D) https://orcid.org/0000-0003-1337-3327 \\ Email: cristianohordones@gmail.com
}

\author{
Antonio Zoratto Sanvicente ${ }^{1}$ \\ (D) https://orcid.org/0000-0002-2888-8318 \\ Email: antonio.sanvicente@fgv.br
}

${ }^{1}$ Fundação Getulio Vargas, Escola de Economia de São Paulo, São Paulo, SP, Brazil

Received on 09.01.2019 - Desk acceptance on 09.27.2019 - $4^{\text {th }}$ version approved on 03.26.2020

Editor-in-Chief: Fábio Frezatti

Associate Editor: Fernanda Finotti Cordeiro

\begin{abstract}
The aim of this paper is to evaluate the influence of market structure on the competition between banks and to determine whether competition affects their profitability in different countries in Latin America. The study also seeks to compare, between 16 countries in the continent, the levels of concentration, competition, and profitability of the respective banking sectors. This article fills the research gap regarding the structure and market power of banks in emerging countries, by comparing Brazil with the other countries in the continent. The topic is extremely important at a time of debate about the high interest rates in Brazil, the market structure observed, and the alleged effect of this on the high levels of spread between lending and borrowing rates. The research provides evidence for the debate regarding the structure of the banking industry. To evaluate competition, the Panzar-Rosse model was used. Concentration was measured by the Herfindahl-Hirschman index and $\mathrm{CR}_{5}$ ratio. To verify the link between the variables, the hypotheses of the structure-conduct-performance model were tested, via a sample of 16 countries in Latin America, covering the period from 2011 to 2017, using panel data regression. This study, conducted for the banking industry in Latin America, rejected the premises of the structure-conduct-performance (SCP) model, which affirm that concentration reduces competition, causing higher profitability in the sector. In the comparison of the studied variables between the countries in the continent, Brazil presented the lowest competition index. The concentration and profitability assessments, in turn, presented results in line with the mean. The results of the research serve to elucidate the intense debate regarding the structure of the banking market. Moreover, they serve as a scientific basis for regulators' actions, aiming to incentivize competition and reduce bank spread.
\end{abstract}

Keywords: banks, concentration, competition, profitability, Latin America. 


\section{INTRODUCTION}

Banks play a crucial role in the economy. They act as conductors of monetary policy, they operate the payments system, and they are an important source of credit for families, businesses, and government. In general, banks can be defined as institutions whose operations consist of granting loans and receiving deposits from the public, playing a crucial role in allocating capital in the economy (Freixas \& Rochet, 2008).

Studies such as those of Calomiris and Kahn (1991), Diamond (1984), Diamond and Rajan (2001), Fama (1985), and Holmstrom and Tirole (1998) have highlighted that developed banking systems stimulate economic growth, increasing fundraising and improving the quality of investments.

Globalization, technological advances, and episodes of financial crisis, in the last two decades, have profoundly changed banking activity in Latin America and forced national banking authorities to deregulate and restructure the domestic banking industries (Yildirim \& Philippatos, 2007). The financial markets have been opened up to foreign participation, in order to increase competition and efficiency. The government efforts to promote large-scale privatization, mergers and acquisitions, and unprecedented growth in foreign participation have profoundly changed competitive conditions in the banking sector.

In general, although competition is widely accepted as a positive phenomenon for manufacturing industries, it has historically been a very controversial question for the banking sector. A certain degree of competition is generally perceived as essential and desirable for improving the sector's efficiency in providing financial services. Moreover, competition between banks can help to improve the price, quality, and availability of products offered to customers, as well as promoting financial innovation, introducing new technologies for the consumer. Rajan and Zingales (1998) argue that an increase in competition can stimulate economic growth, increasing supply and reducing the cost of credit for families and businesses. For another strand of the literature, environments with greater competition are more susceptible to banking crises. Hellman et al. (2000) suggest that in markets in which competition is lower, banks have higher profit margins and are more capitalized and stable. Moreover, Allen and Gale (2004) argue that, depending on their size and capitalization, banks may be pressured into taking on higher risk in response to the intensity of competition.

Various papers have presented the impact of the structure of the banking sector and of bank competition on industrial development. Cetorelli and Gambera (2001) examined the role performed by the concentration of the banking sector on companies' access to sources of financing. The authors showed that bank concentration promotes the growth of industries that are, naturally, big users of external credit, although bank concentration has a negative effect on general economic growth. Claessens and Laeven (2005) disagree, however, by observing that the theory of industrial organization indicates that market concentration is not necessarily a good proxy for an industry's competitiveness. In their paper, they found no evidence that banking sector concentration explains industrial sector growth.

Such considerations are formulated in the context of explaining banks' market power and performance. One of the main theories for studying market power is the structure-conduct-performance (SCP) model, from Bain (1951), which primarily implies that concentration (a characteristic of structure) reduces competition (a characteristic of conduct), causing higher profitability (a measure of performance) in the sector. However, another strand of the literature, the efficiency hypothesis, interprets the relationship between profitability and concentration in terms of greater efficiency. The efficiency hypothesis formalizes the concept that more efficient organizations have lower costs, which in turn causes higher profits.

The theory of industrial organization offers at least two different main measures for evaluating bank competition. The first is based on the model developed by Bresnahan (1982) and Lau (1982), in which an index is estimated that measures the degree of competition by testing industrylevel data. The second is the H-statistic, developed in the works of Panzar and Rosse (1987) and Rosse and Panzar (1977), used in this paper. This method aims to measure up to what point changes in input prices are reflected in revenues, supposing that the market is in equilibrium. The approach of Panzar and Rosse (P-R) has been widely applied to examine the competitive structure in various banking markets.

In Brazil, there is a great debate around the relationship between market power and the high profitability rates of banks. According to the Brazilian Federation of Banks (Febraban, 2018, p. 39): "The substantial fall in the basic interest rate since 2016, supposedly unaccompanied by a similar movement in bank interest rates and spreads, has provoked an intense debate in society."

The choice of the SCP model is warranted due to the fact that public opinion attributes, in Latin America, the high profitability of banks to the structure (concentration) and 
market power (competition), and not to banks' efficiency. The debate, therefore, is centered on the concentrationcompetition-profit triad. To illustrate, it is possible to verify frequent comparisons in the press every year between the result of the headquarters of the Spanish bank Santander and its subsidiaries in the continent (UOL, 2020).

Thus, this paper seeks to evaluate the influence of the market structure on the competition between banks and to determine if competition affects their profitability in different countries of Latin America, verifying whether the hypotheses of the SCP model apply to the continent.
The paper also seeks to compare, between 16 countries in the continent, the levels of concentration, competition, and profitability of the banking sectors.

It is noted that the evidence found in this study contributes to the debate around the structure and market power of the banking industry in Latin America, as well as serving as a scientific basis for regulators' actions, with the aim of improving the competitive environment. Moreover, this article fills a research gap regarding the structure and market power of banks in emerging countries, focusing on Latin America.

\section{HISTORY AND CHARACTERISTICS OF THE BANKING SECTOR IN LATIN AMERICA}

The financial systems in Latin America are marked by similar characteristics: the financial depth is limited; the financial sectors are based on banks, as the stock markets are mostly small and illiquid and the corporate debt markets even more so; the intermediation margins are high in comparison with international standards; the concentration of the banking sector has increased; and bank loans are small in relation to economic activity (Singh et al., 2005).

Banks in Latin America have tended toward consolidation since the 1990s, as a result of the entry of foreign institutions, of privatizations, and of merger and acquisition processes (Peria \& Moky, 2004). According to Fazio et al. (2013), the process of consolidation of the financial system in Latin America has not only changed the performance and quality of banking services, but also the market structure, turning some institutions into global systemically important banks (G-SIBs) for the financial systems of their respective countries.

Yeyati and Micco (2007) observed that, unlike Europe and the United States, the consolidation of the banking system in Latin America has been broadly driven by the acquisition of local banks by foreign institutions, which has resulted in economies of scale and lower competition, enabling efficiency gains and higher profitability. External investment has helped the barely capitalized markets in Latin America, and bank consolidation has created benefits for consumers, such as, for example, increasing the quality of services (Berger \& Mester, 2003).

According to Fase and Abma (2003), in emerging countries, banks function as the main transmission channel of monetary policy and, due to an underdeveloped capital market, they act as the main source of resources for companies. Banking activity is crucial for countries' development because the banking system is an important piece of financial development, which serves as a basis for economic growth (Khan \& Senhadji, 2000; Levine, 2003).
In fact, limited access to bank credit and uncertainty about financial stability are factors that have contributed to the economic volatility in the region. During the 1980 s and, especially, the 1990s, the banking sector in Latin America underwent profound transformations. According to Singh et al. (2005), structural reforms were adopted in the region, particularly the liberalization of interest rates, large-scale privatizations of public banks, and the facilitation of entry of foreign banks.

Banking crises, deregulation, and globalization of financial services have caused a significant increase in the presence of foreign banks in emerging markets since the second half of the 1990s. For Hawkins and Mihaljek (2001), the entry of foreign banks has significantly increased the competitive pressure on banks.

For Claessens et al. (2001), the entry of foreign banks heightens the threat of increased competition, which alters the behavior of the domestic banks and reduces their market power. The evidence suggests that this has occurred in Latin America: greater entry of foreign banks has caused lower interest margins and profits in domestic banks (Yildirim \& Philippatos, 2007).

The consolidation of the banking system has become more advanced in Latin America in comparison with other emerging markets. The state has actively participated in the restructuring and implementation of privatization programs in the region, although in countries such as Brazil and Argentina, large banks have remained under state control.

Despite the strong entry of foreign banks into Latin America as of the 1990s, it is noted that Brazil, the biggest economy in the region, has only one foreign bank among the 10 largest as classified by total assets. The low participation of foreign banks in the country, in comparison with their peers in Latin America, can be verified in Table 1. 
Table 1

Participation of foreign banks by total assets of the banking system (\%)

\begin{tabular}{|c|c|c|c|c|c|}
\hline Country & 1995 & 2001 & 2008 & 2010 & 2013 \\
\hline Argentina & 26.0 & 40.0 & 31.0 & 26.0 & 27.0 \\
\hline Brazil & 9.0 & 23.0 & 21.0 & 18.0 & 16.0 \\
\hline Chile & 31.0 & 39.0 & 41.0 & 39.0 & 27.0 \\
\hline Colombia & 6.0 & 22.0 & 22.0 & 20.0 & 14.0 \\
\hline Costa Rica & 0.0 & 23.0 & 36.0 & 31.0 & 29.0 \\
\hline Ecuador & 0.0 & 70.0 & 3.0 & 2.0 & 16.0 \\
\hline El Salvador & 1.0 & 12.0 & 94.0 & 93.0 & 98.0 \\
\hline Guatemala & 6.0 & 7.0 & 11.0 & 10.0 & 31.0 \\
\hline Guyana & 0.0 & 18.0 & 57.0 & 56.0 & 0.0 \\
\hline Honduras & 2.0 & 10.0 & 50.0 & 50.0 & 55.0 \\
\hline Jamaica & 24.0 & 44.0 & 94.0 & 95.0 & 93.0 \\
\hline Mexico & 2.0 & 51.0 & 84.0 & 85.0 & 71.0 \\
\hline Peru & 52.0 & 41.0 & 51.0 & 49.0 & 50.0 \\
\hline Uruguay & 24.0 & 43.0 & 52.0 & 54.0 & 73.0 \\
\hline Venezuela & 5.0 & 38.0 & 26.0 & 17.0 & 16.0 \\
\hline
\end{tabular}

Source: Cull et al. (2017).

The consolidation process has increased the concentration in the banking sector in Latin America. According to Berger et al. (2015), while the expectations of policy makers was that a higher concentration would lead to more competition and improved efficiency, there was the possibility that gains in competitiveness would not materialize and that, instead, the banks' market power would increase.
Table 2 shows the market share of the three biggest banks $\left(\mathrm{CR}_{3}\right.$ ratio) of countries in the region, together with comparative data for Japan, the United Kingdom, and the United States. In all the countries, with the exception of Ecuador and Venezuela, the market share of the three biggest banks increased, in the comparison between 2000 and 2005. Colombia, Uruguay, and Brazil, which is the biggest economy in the region, saw significant increases in concentration between 2000 and 2015 .

Table 2

Bank concentration $\left(C R_{3}\right.$ ratio, \%)

\begin{tabular}{|c|c|c|c|c|}
\hline Country & 2000 & 2005 & 2010 & 2015 \\
\hline Argentina & 32.3 & 46.4 & 34.0 & 51.8 \\
\hline Bolivia & 47.4 & 50.3 & 57.1 & 47.5 \\
\hline Brazil & 38.7 & 46.1 & 61.7 & 76.4 \\
\hline Chile & 38.4 & 55.1 & 52.1 & 42.6 \\
\hline Colombia & 32.1 & 43.4 & 50.1 & 70.7 \\
\hline Ecuador & 54.4 & 49.7 & 54.5 & 54.1 \\
\hline Mexico & 57.4 & 60.4 & 53.3 & 54.4 \\
\hline Peru & 61.9 & 76.9 & 74.2 & 79.4 \\
\hline Paraguay & 45.4 & 47.8 & 49.5 & 50.6 \\
\hline Uruguay & 34.9 & 57.7 & 61.6 & 69.4 \\
\hline Venezuela & 44.7 & 36.4 & 68.7 & 57.0 \\
\hline Japan & 35.0 & 40.0 & 44.2 & 44.7 \\
\hline United Kingdom & 30.4 & 49.4 & 56.0 & 51.4 \\
\hline United States & 21.4 & 29.8 & 31.6 & 34.8 \\
\hline
\end{tabular}

Source: Berger et al. (2015) and World Bank (2018). 


\section{LITERATURE REVIEW}

Although there is considerable literature with regards to studying the relationships between concentration, competition, and profitability in the banking sector, most of the studies cover the banking markets in the United States and Europe.

Shaffer (1982) was one of the first to apply the P-R model to banks. Using banks in the state of New York in 1979, he found that the market was characterized by monopolistic competition. For Canadian banks, Nathan and Neave (1989) also used the P-R methodology. The results for Canada are consistent with those found by Shaffer (1989), who used the methodology of Bresnahan (1982) to verify that the market was in a state of monopolistic competition.

Some other studies have applied the P-R methodology to non-North American and non-European banking systems. For Japan, for example, Molyneux et al. (1996) found evidence of a monopoly situation in the period from 1986 to 1988.
For Latin America, Yeyati and Micco (2007) found evidence that the banking system for eight countries, during the period from 1996 to 2002, was characterized by monopolistic competition.

In a wide study, Claessens and Laeven (2004) also tested bank competition using the P-R methodology with data from 50 countries for the period from 1994 to 2001 . The results found show that most of the countries present a banking market characterized by monopolistic competition, with an $\mathrm{H}$-statistic varying between 0.6 and 0.8 .

A large number of studies have sought to test the competition in the banking sector. The countries covered, the periods, and some of the assumptions used vary between the studies. Although the discoveries vary to a certain extent, in general, the studies reject both perfect collusion and perfect competition and find evidence of monopolistic competition, as Table 3 indicates. Thus, the results are generally in line with the evidence found in this paper.

Table 3

Empirical results using Panzar-Rosse's (1987) model

\begin{tabular}{lccc}
\hline Authors & Period & Countries studied & Results \\
\hline Shaffer (1982) & 1979 & United States & Monopolistic competition \\
\hline Nathan and Neave (1989) & $1982-1984$ & Canada & Monopolistic competition \\
\hline Lloyd-Williams et al. (1996) & $1986-1988$ & Japan & Monopoly \\
\hline Molyneux et al. (1994) & $1986-1989$ & 5 European countries & Monopolistic competition \\
\hline Vesala (1995) & $1985-1992$ & Finland & Monopolistic competition \\
\hline Molyneux et al. (1996) & $1986-1988$ & Japan & Monopoly \\
\hline Coccorese (2004) & $1997-1999$ & Italy & Monopolistic competition \\
\hline Rime (1999) & $1987-1994$ & Switzerland & Monopolistic competition \\
\hline Bikker and Groeneveld (2000) & $1989-1996$ & 15 European countries & Monopolistic competition \\
\hline De Bandt and Davis (2000) & $1992-1996$ & France, Germany, and Italy & Monopolistic competition \\
\hline Bikker and Haaf (2002) & $1991-1998$ & 23 OECD countries & Monopolistic competition \\
\hline Casu and Girardone (2006) & $1997-2003$ & European Union & Monopolistic competition \\
\hline Matthews et al. (2007) & $1980-2002$ & United Kingdom & Monopolistic competition \\
\hline Sun (2011) & $1995-2009$ & United Kingdom and United States & Monopolistic competition \\
\hline
\end{tabular}

OECD = Organisation for Economic Co-operation and Development.

Source: Matthews and Thompson (2014).

Berger and Hannan (1989) investigated the commonly observed relationship between market concentration and profitability. Using data for banks from the United States covering the period from 1983 and 1985, they discovered that banks in more concentrated markets charge higher rates on loans and pay lower rates on deposits. Berger
(1995) also explored the relationship between market power and profit. However, limited evidence was found for any specific theory of bank profits, including the SCP hypotheses.

Jansen and de Haan (2003) analyzed the relationship between concentration, competition, efficiency, and 
profitability in the European banking sector, using panel data regressions. The results suggest that there is no evidence of any relationship between competition and concentration, nor between concentration and profitability.

For Brazil, Nakane (2001) implemented Lau's (1982) model to empirically test market power in the banking sector. It was noted that the banking sector is highly competitive, but the perfect competition hypothesis was rejected.

Coelho et al. (2013) studied the relationship between concentration and competition in the Brazilian banking market using the approach of Bresnahan and Reiss (1991). The authors sought to identify whether, in a highly concentrated market, the public banks are able to compel the private banks to have more competitive behavior. It was found that the presence of more private banks increases competition, while the presence of public banks has neutral results. In a similar study, Martins et al. (2014) found the opposite results. Using the methodologies of Bresnahan (1982) and Lau (1982), the authors observed that public banks have important participation in competition.

Finally, in Brazil, the paper by Barbosa et al. (2015) is worth mentioning, which studied the banking competition between institutions that offer classic bank products as well as other products, and institutions that offer only classic bank products. The authors used the methodology of Panzar and Rosse (1987), verifying that banks that offer a bigger product range have more market power than banks that offer only classic products.

Berstain and Fuentes (2005) studied the relationship between bank concentration and price rigidity in Chile. With a sample that analyzed the period from 1995 to 2002, the authors discovered that the banks' deposit rates react more slowly to changes in market rates when there is greater bank concentration.

Smirlock (1985) also sought to verify the relationship between bank concentration and profitability, verifying that concentration has a significant impact on profitability, with which it presents a positive correlation.

For the banking sector in Mexico, the hypotheses of the SCP model were rejected for a sample of 19 banks in the period from 1997 to 2003, using panel data, in the research of Guerrero et al. (2005).

Finally, the paper by Bikker and Haaf (2002) is worth mentioning, which explored the hypotheses of the SCP model, using the P-R method, to verify the level of competition in the European banking market. The authors found a negative relationship between concentration and competition, concluding that an increase in concentration damages competition.

In summary, it is possible to conclude that there is no consensus in the literature regarding the relationship between concentration, competition, and profitability in the banking sector. Various methodologies have been applied, including the SCP, and the results diverge regarding the impact of structure on market power and of this on the bank performance metric.

Therefore, in line with the literature, this study tested the relationship between structure, market power, and profitability. Using panel data, the hypotheses of the SCP model were tested to verify the impact of bank concentration on competition and the impact of this on banks' profitability.

This paper therefore contributes to the academic literature, testing the hypotheses of the SCP model for Latin America, a market that is barely explored in research on the microeconomics of banking.

\section{METHODOLOGY AND DATABASE}

\subsection{Empirical Tests}

\subsubsection{Concentration}

To assess the level of concentration, the HerfindahlHirschman index (HHI) was used, defined by the sum of the squares of the market shares of the banks. The HHI is the main measure used by regulators to measure the level of concentration of a market. The $\mathrm{CR}_{\mathrm{k}}$ indicator was used to measure the combined market share of the $\mathrm{k}$ largest banks of each country. In both indices, the concentration in total assets was evaluated. The indices are explained below.

$$
\begin{gathered}
C R_{k}=\sum_{i=1}^{k} S_{i} \\
H H I=\sum_{i=1}^{n} S_{i}^{2}
\end{gathered}
$$

in which $k$ is the quantity of banks chosen, $n$ is the number of banks in the sector, and $S_{i}$ is the market share of bank $i$.

\subsubsection{Competition}

To determine the competition regime, Panzar and Rosse's (1987) model was used, which proposes estimating the elasticities of a bank's revenue to variations in input prices. The sum of the elasticities of revenue in relation 
to the factor prices is known as the H-statistic, assessed as according to Table 4 .

Table 4

Interval of the $\mathrm{H}$-statistic values

\begin{tabular}{cc}
\hline Interval & Result \\
\hline $\mathrm{H}<0$ & Monopoly \\
\hline $0<\mathrm{H}<1$ & Monopolistic competition \\
\hline $\mathrm{H}=1$ & Perfect competition \\
\hline
\end{tabular}

Source: Panzar and Rosse (1987).

Panzar and Rosse (1987) assume that banks operate in long-term equilibrium and that their performance is influenced by the actions of the other market participants.

The model proposes that the number of banks and output, in the long term, are determined by the maximization of profit at the levels of the banking sector and of the bank. Formally, banks maximize their profit when marginal revenue is equal to marginal cost:

$$
R_{j}\left(q_{i}, n, z_{i}\right)=C_{i}\left(q_{i}, w_{i}, x_{i}\right)
$$

in which $R$ and $C$ are marginal revenue and marginal cost, respectively, $q_{i}$ is the output of bank $i, n$ is the number of banks, $z_{i}$ is the vector of exogenous variables that influence the revenue function of bank $i, x_{i}$ is the vector of exogenous variables that influence the cost function of bank $i$, and $w_{i}$ is the vector of input prices.

Market power is gauged by the measure in which the bank's revenue is affected by a change in input prices. The $\mathrm{P}-\mathrm{R}$ model defines the sum of the elasticities of revenue in relation to input prices as a measure of the degree of competition.

The reduced form of the model is:

$$
\ln \left(\mathrm{INTR}_{i t}\right)=\alpha_{0}+\sum_{f}^{F} B_{f} \ln \left(\mathrm{w}_{f, i t}\right)+\sum_{k}^{K} \gamma_{k} \mathrm{X}_{k, i t}+\varepsilon_{i t}
$$

in which $\mathrm{INTR}_{i t}$ is the ratio between the total revenue and the total assets of bank $i$ at time $t, \mathrm{w}_{i t}$ represents the input prices, and, finally, $\mathrm{X}_{k, i t}$ contains the control variables.
For this study, we used the model proposed in the papers by Bikker and Groeneveld (2000) and Bikker and Haaf (2002):

$$
\ln \mathrm{INTR}=\alpha+\beta \ln \mathrm{INTE}+\gamma \ln \mathrm{PE}+\delta \ln \mathrm{CE}+\lambda \ln \mathrm{BSF}+\eta \ln \mathrm{OI}+\varepsilon
$$

in which INTR is the ratio between the total interest revenue and total assets (intermediation revenue), INTE is the ratio between annual interest expenses and total deposits (intermediation cost), $\mathrm{PE}$ is the ratio between spending on personnel and total assets, $\mathrm{CE}$ is the ratio between physical capital plus other expenses and fixed assets, BSF is the proxy for bank-specific factors, and OI is the ratio between other revenues and total assets.

Bikker and Groeneveld (2000), following Molyneux et al. (1994), adopted the ratio between total interest revenue and total assets (INTR) as the dependent variable. The decision to take INTR as the dependent variable is in line with Panzar and Rosse's (1987) model, due to the fact that financial intermediation is the main business of most banks. INTE, PE, and CE are unit prices of the banks' inputs: fundraising, workforce, and capital or proxies of these prices.

In line with the papers by Nathan and Neaves (1989) and Shaffer (1982), the ratio between other revenues and total assets (OI) was added as an explanatory variable, to control for the influence of the generation of other revenues on the marginal revenue and cost functions underlying the model.
Bank-specific factors (BSF) are other explanatory factors that reflect differences in risks, costs, size, and structure of the banks. The risk component can be represented by the ratio between net equity and total assets (EQ) and by the ratio between loans and total assets (LO). Finally, total assets (TA) is used as a scale factor. The estimation method employed was pooled ordinary least squares (POLS).

Finally, to evaluate the level of competition, Panzar and Rosse's (1987) competition measure was used, that is, the $\mathrm{H}$-statistic, defined as the sum of the elasticities of revenues in relation to input prices, which corresponds to:

$$
\mathrm{H}=\beta+\gamma+\delta
$$

\subsubsection{Profitability}

To measure profitability, the indicators return on assets (ROA) and return on equity (ROE) were used, which are considered by the literature as the main indicators to determine a bank's profitability. The measures are calculated as follows: 


$$
\begin{gathered}
\mathrm{ROA}=\frac{\text { operating income }}{\text { total assets }} \\
\mathrm{ROE}=\frac{\text { net income }}{\text { net equity }}
\end{gathered}
$$

Table 5, extracted from the database of the Latin American Federation of Banks (Felaban, 2018), shows the returns on total assets and net equity of the banks of

\begin{tabular}{|c|c|c|c|c|c|c|}
\hline & & ROA & & & ROE & \\
\hline Country & 2015 & 2016 & 2017 & 2015 & 2016 & 2017 \\
\hline Argentina & 3.34 & 2.82 & 2.24 & 27.23 & 25.07 & 19.37 \\
\hline Bolivia & 1.05 & 1.14 & 1.00 & 14.01 & 14.27 & 14.00 \\
\hline Brazil & 1.14 & 0.93 & 1.16 & 16.44 & 12.03 & 13.57 \\
\hline Chile & 1.07 & 0.92 & 1.01 & 14.19 & 10.89 & 12.02 \\
\hline Colombia & 1.91 & 2.07 & 1.30 & 14.30 & 15.59 & 9.99 \\
\hline Costa Rica & 0.81 & 0.98 & 0.64 & 7.25 & 8.81 & 5.90 \\
\hline Ecuador & 0.88 & 0.62 & 1.02 & 8.22 & 6.30 & 9.39 \\
\hline El Salvador & 1.00 & 0.86 & 0.89 & 7.35 & 6.43 & 6.83 \\
\hline Mexico & 1.27 & 1.24 & 1.53 & 12.19 & 12.50 & 14.76 \\
\hline Panama & 1.40 & 1.23 & 1.48 & 13.85 & 11.61 & 12.96 \\
\hline Paraguay & 2.09 & 1.97 & 2.08 & 20.13 & 17.73 & 18.21 \\
\hline Peru & 1.96 & 2.03 & 2.00 & 20.29 & 18.41 & 17.05 \\
\hline Dominican Republic & 1.77 & 1.70 & 1.63 & 18.17 & 17.00 & 15.76 \\
\hline Uruguay & 0.89 & 0.23 & 0.98 & 12.61 & 3.00 & 11.62 \\
\hline Mean & 1.47 & 1.34 & 1.35 & 14.73 & 12.83 & 12.96 \\
\hline Standard deviation & 0.67 & 0.67 & 0.47 & 5.32 & 5.57 & 3.87 \\
\hline Maximum & 3.34 & 2.82 & 2.24 & 27.23 & 25.07 & 19.37 \\
\hline Minimum & 0.81 & 0.23 & 0.64 & 7.25 & 3.00 & 5.90 \\
\hline
\end{tabular}
the main economies in Latin America.

Table 5

Return on assets (ROA) and return on equity (ROE) - Banking sector in Latin America (\%)

Source: Felaban (2018).

\subsection{SCP Model}

Two hypotheses originating from Bain’s (1951) SCP model are tested.

To test his model, Bain (1952) used data from the manufacturing industry of the United States, covering the period from 1936 to 1940 . The results suggest that the high concentration has an impact on the profitability of the businesses.

Matthews and Thompson (2014) argue that, in the SCP model, a small number of large firms, in a concentrated market, is more likely to have less competitive behavior. For the banking sector, Degryse et al. (2009) affirm that the SCP model used the HHI index as a proxy for bank concentration in the econometric model:

$$
\Pi_{i j t}=\alpha_{0}+\alpha_{1} \mathrm{HHI}_{j t}+\sum_{k} \gamma_{k} X_{k^{\prime} i j t}+\varepsilon_{i j t}
$$

in which $\Pi_{i j t}$ is the profitability measure of bank $i$ in banking sector $j$ at time $t$; $\mathrm{HHI}_{j t}$ is the concentration measure in market $j$ at time $t$, and $X_{k, i j t}$ is the vector of control variables that can affect bank profitability. The model implies that $\alpha_{1}>0$, that is, a more concentrated market (structure) causes greater market power (conduct), which leads to higher profits (performance).

Degryse et al. (2009) affirm that the SCP model indicates that a high concentration in the banking sector causes lower competition, which generates higher profitability in the sector.

Therefore, the SCP model implies two hypotheses:

$\mathrm{H}_{1}$ : a higher degree of concentration leads to lower competition.

$\mathrm{H}_{2}$ : lower competition leads to higher profitability.

Therefore, the objective of the paper is to investigate the link between indicators of concentration, profitability, and competition, testing the two hypotheses of the SCP model. For this, panel data regression analysis was used. 


\subsection{Regression Analysis}

The relationship between concentration, competition, and profitability is investigated using panel data regression analysis, according to each hypothesis shown in Figure 1. In both cases, the model is estimated using panel data with fixed effects.

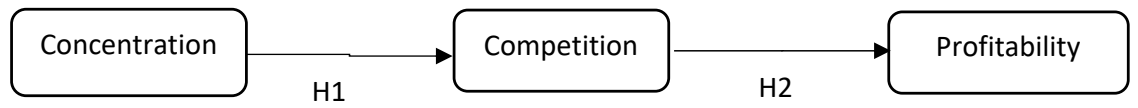

Figure 1 The two hypotheses to be tested Source: Elaborated by the authors.

Thus, country level data are used for the concentration, competition, and profitability variables, to explore the relationship between these and verify whether the hypotheses of the SCP model are sustained for Latin America.

\section{$H_{1}$ : a higher degree of concentration leads to lower competition.}

A high degree of concentration indicates that a small number of participants have considerable control over market share, which, in theory, causes less competitive behavior. To verify this relationship, a panel data analysis is carried out with the $\mathrm{H}$-statistic, as a measure of competition, as the dependent variable. For concentration, the $\mathrm{CR}_{5}$ and $\mathrm{HHI}$ indicators of total assets are used as independent variables. The choice of the $\mathrm{CR}_{5}$, the combined market share of the five largest banks, is in line with the study by Bikker and Groeneveld (2000), conducted for European banks. As an independent variable, the logarithm of the quantity of banks is also used.

Therefore, the regression is given by:

$$
\begin{aligned}
& H_{i t}=\alpha_{i}+\beta_{1} H_{H I}+\beta_{2} \log n_{i t}+\varepsilon_{i} \\
& H_{i t}=\alpha_{i}+\beta_{1} C R_{5 i t}+\beta_{2} \log n_{i t}+\varepsilon_{i}
\end{aligned}
$$

For both regressions, the concentration coefficient $\left(\beta_{1}\right)$ is expected to have a negative sign, indicating that competition decreases with an increase in market concentration. In general, a large quantity of banks indicates greater potential competition. For that reason, a positive sign is expected for the $\beta_{2}$ coefficient.

Bikker and Groeneveld (2000) found a negative relationship between concentration and competition, using Spearman's correlation coefficient, concluding that an increase in concentration damages competition.

\section{$\mathrm{H}_{2}$ : less competition leads to higher profitability.}

For the second hypothesis of the SCP model, it is verified whether less competition in the banking sector gives the banks greater power to define prices and reduce costs, causing higher profitability. For this, a regression analysis is carried out of profitability as a function of a measure of competition. The explanatory variable is the H-statistic, proposed by Panzar and Rosse (1987) to measure the competition in the sector. The dependent variable, profitability, is measured by the ROA and ROE indicators.

The regressions are presented below.

$$
\begin{aligned}
& \operatorname{ROA}_{i t}=\alpha_{i}+\beta_{1} H_{i t}+X_{i t}+\varepsilon_{i} \\
& \operatorname{ROE}_{i t}=\alpha_{i}+\beta_{1} H_{i t}+X_{i t}+\varepsilon_{i}
\end{aligned}
$$

The following are used as control variables: the annual growth in gross domestic product (GDP), the basic interest rate, and the annual inflation of each country.

Jansen and de Haan (2003) do not find a link between bank competition and profitability for European banks, regressing the returns on assets and net equity using the $\mathrm{H}$-statistic.

\subsection{Data}

The data, expressed in time units (years), from the variables used in this study refer to the financial institutions that operated in Latin America between 2011 and 2017 and were extracted for the Orbis Bank Focus database. According to the criteria of the database, only institutions denominated as commercial banks, investment banks, and state-controlled banks were chosen. The sample has 586 financial institutions distributed among various countries of the region, as detailed in Table 6.

For the control variables (inflation, interest rate, and GDP) used in regressions 12 and 13, the information was extracted from the World Bank database. 
Table 6

Quantity of financial institutions in the sample by country (n)

\begin{tabular}{cc}
\hline Country & $\mathbf{n}$ \\
\hline Argentina & 53 \\
\hline Bolivia & 18 \\
\hline Colombia & 35 \\
\hline Brazil & 145 \\
\hline Chile & 24 \\
\hline Costa Rica & 18 \\
\hline Ecuador & 28 \\
\hline El Salvador & 18 \\
\hline Jamaica & 13 \\
\hline Mexico & 52 \\
\hline Panama & 73 \\
\hline Paraguay & 20 \\
\hline Peru & 27 \\
\hline Dominican Republic & 23 \\
\hline Uruguay & 15 \\
\hline Venezuela & 24 \\
\hline Total & 586 \\
\hline
\end{tabular}

Source: Prepared by the authors.

\section{RESULTS ANALYSIS}

\subsection{Concentration Measures}

To verify the degree of banking concentration in the countries in Latin America, the HHI was used, which varies from 0 to 10,000 points. According to the
Department of Justice of the United States (2010), a market with fewer than 1,500 points is classified as low concentration, one with 1,500-2,500 points is considered moderately concentrated, and a market with more than 2,500 points is considered highly concentrated.

Table 7

Concentration measures based on total assets - Herfindahl-Hirschman index (HHI) and $C_{k}-2017(\%)$

\begin{tabular}{|c|c|c|c|c|c|}
\hline Country & HHI & $\begin{array}{l}\mathrm{CR}_{3} \\
(\%)\end{array}$ & $\begin{array}{l}\mathrm{CR}_{5} \\
(\%)\end{array}$ & $\begin{array}{l}\mathrm{CR}_{10} \\
(\%)\end{array}$ & $\begin{array}{l}\text { Quantity of banks } \\
\text { (n) }\end{array}$ \\
\hline Argentina & 891 & 21.0 & 57.0 & 77.0 & 53 \\
\hline Bolivia & 958 & 41.0 & 61.0 & 90.0 & 18 \\
\hline Colombia & 1,113 & 50.0 & 67.0 & 83.0 & 35 \\
\hline Brazil & 1,187 & 48.0 & 74.0 & 88.0 & 145 \\
\hline Chile & 1,059 & 41.0 & 66.0 & 92.0 & 24 \\
\hline Costa Rica & 1,473 & 58.0 & 76.0 & 94.0 & 18 \\
\hline Ecuador & 1,038 & 43.0 & 58.0 & 83.0 & 28 \\
\hline El Salvador & 1,227 & 51.0 & 71.0 & 92.0 & 18 \\
\hline Jamaica & 1,568 & 59.0 & 78.0 & 98.0 & 13 \\
\hline Mexico & 872 & 41.0 & 58.0 & 81.0 & 52 \\
\hline Panama & 2,400 & 60.0 & 70.0 & 82.0 & 73 \\
\hline Paraguay & 1,243 & 48.0 & 66.0 & 87.0 & 20 \\
\hline Peru & 2,078 & 71.0 & 86.0 & 94.0 & 27 \\
\hline
\end{tabular}


Table 7

Cont.

\begin{tabular}{|c|c|c|c|c|c|}
\hline Country & HHI & $\begin{array}{l}\mathrm{CR}_{3} \\
(\%)\end{array}$ & $\begin{array}{l}\mathrm{CR}_{5} \\
(\%)\end{array}$ & $\begin{array}{l}\mathrm{CR}_{10} \\
(\%)\end{array}$ & $\begin{array}{l}\text { Quantity of banks } \\
\text { (n) }\end{array}$ \\
\hline Dominican Republic & 1,664 & 64.0 & 83.0 & 94.0 & 23 \\
\hline Uruguay & 2,239 & 66.0 & 82.0 & 98.0 & 15 \\
\hline Venezuela & 1,124 & 49.0 & 64.0 & 87.0 & 24 \\
\hline Mean & 1,383 & 51.0 & 70.0 & 89.0 & 37 \\
\hline Standard deviation & 468 & 12.0 & 9.0 & 6.0 & 32 \\
\hline Maximum & 2,400 & 71.0 & 86.0 & 98.0 & 145 \\
\hline Minimum & 872 & 21.0 & 57.0 & 77.0 & 13 \\
\hline
\end{tabular}

Note: $\mathrm{HHI}$ is the sum of the squares of the market shares of the banks and $C R_{k}$ is the combined market share of the $k$ biggest banks of each country.

Source: Prepared by the authors with data from Orbis Bank Focus.

According to Table 7, it was verified that Mexico is the country with the lowest concentration in the sample, with 872 points, while Panama presents the highest concentration level, with 2,400. Brazil has the greatest quantity of banks in the sample and has a lower concentration index than the mean, of 1,383 .

Besides being the biggest economy in the region, Brazil has the biggest banking market, corresponding to more than $50 \%$ of all assets in Latin America, as according to Figure 2.

\section{Total Assets - September/2018}

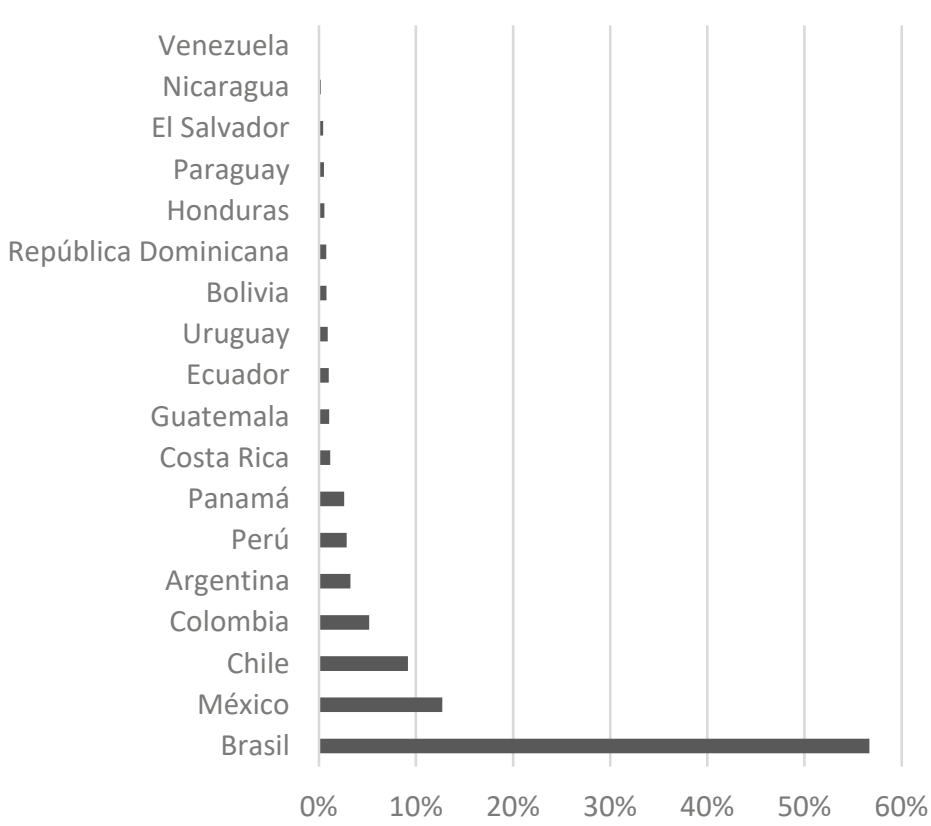

Figure 2 Share of total assets in USD in the region by country - September of 2018

Source: Felaban (2018).

The banking industry tends toward concentration due to the fact that it is a capital-intensive sector. The values found for concentration are in line with the studies conducted for other markets, as can be observed in the papers by Bikker and Groeneveld (2000), Bikker and Haaf (2002), Casu and Girardone (2006), and Smirlock (1985).

\subsection{Competition Measure - H-statistic}

Table 8 shows the results of regression 5 , of the P-R model, in the period from 2011 to 2017, for 586 banks from 16 countries in Latin America. The three input unit prices of the banks contribute significantly to explaining 
the banks' interest revenue. The fundraising factor, INTE, is the one that contributes the most to determining the $\mathrm{H}$-statistic, as expected.

All the countries have a statistic that characterizes their banking sector as operating under monopolistic competition. The banking market of Brazil, the biggest economy in the region, stands out as having the lowest index (0.49), therefore being the country of the region with the lowest competition in the banking market. It is also important to highlight the markets of Chile and Uruguay, which have indices higher than 0.80 , the highest in the region, and which are in line with countries in Europe, as verified in the papers by Bikker and Groeneveld (2000) and Bikker and Haaf (2002).

Table 8

Empirical results of Panzar and Rosse's (1987) model - Input prices and H-statistic

\begin{tabular}{|c|c|c|c|c|}
\hline & INTE & PE & CE & H-statistic \\
\hline Argentina & 0.3720 & 0.1695 & 0.0542 & 0.5956 \\
\hline Bolivia & 0.2282 & 0.5008 & 0.0000 & 0.7291 \\
\hline Brazil & 0.4002 & 0.0872 & 0.0000 & 0.4873 \\
\hline Chile & 0.2133 & 0.6041 & 0.0068 & 0.8242 \\
\hline Colombia & 0.4492 & 0.3335 & -0.0008 & 0.7819 \\
\hline Costa Rica & 0.4825 & 0.2691 & 0.0046 & 0.7562 \\
\hline El Salvador & 0.1040 & 0.5654 & 0.0032 & 0.6727 \\
\hline Ecuador & 0.1234 & 0.4288 & 0.0000 & 0.5522 \\
\hline Jamaica & 0.3818 & 0.3454 & -0.0022 & 0.7250 \\
\hline Mexico & 0.4801 & 0.2267 & 0.0069 & 0.7137 \\
\hline Panama & 0.3108 & 0.2592 & 0.0000 & 0.5700 \\
\hline Paraguay & 0.4960 & 0.1711 & 0.0002 & 0.6674 \\
\hline Peru & 0.0748 & 0.5710 & 0.0081 & 0.6540 \\
\hline Dominican Republic & 0.2948 & 0.3763 & -0.0002 & 0.6708 \\
\hline Uruguay & 0.6021 & 0.2673 & 0.0001 & 0.8695 \\
\hline Venezuela & 0.0711 & 0.5579 & 0.0054 & 0.6343 \\
\hline Mean & 0.32 & 0.36 & 0.01 & 0.68 \\
\hline Standard deviation & 0.16 & 0.16 & 0.01 & 0.10 \\
\hline Maximum & 0.60 & 0.60 & 0.05 & 0.87 \\
\hline Minimum & 0.07 & 0.09 & 0.00 & 0.49 \\
\hline
\end{tabular}

Note: The variables are described in the text.

Source: Prepared by the authors.

The PE variable, which indicates workforce expenses, has a high value for Peru and Chile, representing a weight of $87 \%$ and $73 \%$, respectively, in the competition index of each country. According to Table 9, the banks in Chile and Peru have low overhead rates, one of the main components of which are salaries. Low labor costs enable the banks to have greater flexibility in allocating resources, and, also, to determine the interest rate charged, thus improving competition.

Table 9

Bank overheads - Percentage of total assets (2016)

\begin{tabular}{cc}
\hline Country & \% \\
\hline Colombia & 6.12 \\
\hline Brazil & 5.29 \\
\hline Ecuador & 5.10 \\
\hline Paraguay & 4.87 \\
\hline Bolivia & 4.32 \\
\hline Peru & 3.99 \\
\hline Chile & 2.39
\end{tabular}

Source: World Bank (2018). 


\subsection{Regression Results}

\section{$\mathrm{H}_{1}$ : a higher degree of concentration leads to less} competition.

To verify the relationship between concentration and competition in the banking market, a panel data regression with fixed effects was run, for the period from 2011 to
2017, with data from the banking sector of the 16 Latin countries in the study.

The results, as observed in Table 10, indicate that there is no relationship between the variables $\mathrm{HHI}, \mathrm{CR}_{5}$, and the number of banks, which are independent variables, and competition, represented by the $\mathrm{H}$-statistic of the P-R model.

\section{Table 10}

Competition and concentration: panel data regression - 2011-2017

\begin{tabular}{|c|c|c|}
\hline & \multicolumn{2}{|c|}{ Dependent variable } \\
\hline & \multicolumn{2}{|c|}{$\mathbf{H}$} \\
\hline & 1 & 2 \\
\hline $\mathrm{HHI}$ & $\begin{array}{c}0.003 \\
(0.002)\end{array}$ & \\
\hline $\mathrm{CR}_{5}$ & $\begin{array}{c}0.001 \\
(0.003)\end{array}$ & \\
\hline LOG n banks & $\begin{array}{c}0.026 \\
(0.222)\end{array}$ & $\begin{array}{c}0.028 \\
(0.228)\end{array}$ \\
\hline Number of observations & 112 & 112 \\
\hline $\mathrm{R}^{2}$ & 0.022 & 0.002 \\
\hline Adjusted $\mathrm{R}^{2}$ & -0.155 & -0.178 \\
\hline F statistics $(\mathrm{df}=2 ; 94)$ & 1.053 & 0.103 \\
\hline
\end{tabular}

Note: Values in parentheses indicate standard error.

$H H I=$ Herfindahl-Hirschman index.

${ }^{*} p<0.1 ;{ }^{* *} p<0.05 ;{ }^{* * *} p<0.01$.

Source: Prepared by the authors.

Therefore, the results suggest that concentration (structure) does not influence competition (conduct) in the banking market in Latin America. This result is in line with the paper by Jansen and de Haan (2003) for the European continent.

Although a market with low concentration is perceived as having greater potential competition, the premise does not apply to the banking sector in Latin America. It is noted that a market with only two competitors may present a highly competitive environment, such as in a Bertrand (1883) competition model. Thus, the economics literature shows that there are highly concentrated markets in which there is strong competition, and markets with little concentration with less competition.

\section{$\mathrm{H}_{2}$ : less competition leads to higher profitability.}

The second hypothesis of the SCP model aims to verify if less competition in the banking market enables higher profit margins for the banks. To verify this relationship, the profitability indices, ROA and ROE, were regressed against the $\mathrm{H}$-statistic, a measure of competition. Inflation, the interest rate, and GDP growth were used as control variables.

Table 11

Profitability and competition: panel data regression - 2011-2017

\begin{tabular}{ccc}
\hline \multirow{2}{*}{ ROA } & \multicolumn{2}{c}{ Dependent variable } \\
\cline { 2 - 3 } & $\mathbf{( 1 )}$ & $\mathbf{R O E}$ \\
& 0.268 & $\mathbf{( 2 )}$ \\
\hline \multirow{2}{*}{ Inflation } & $(0.565)$ & 2.471 \\
& -0.445 & $(3.876)$ \\
\hline \multirow{2}{*}{ Interest rate } & $(0.368)$ & -2.139 \\
& $7.591^{*}$ & $(2.527)$ \\
\hline
\end{tabular}




\begin{tabular}{ccc}
\hline & \multicolumn{2}{c}{ Dependent variable } \\
\cline { 2 - 3 } & $\mathbf{R O A}$ & $\mathbf{R O E}$ \\
& $\mathbf{( 1 )}$ & $\mathbf{( 2 )}$ \\
\hline GDP & $8.027^{* * *}$ & $67.702^{* * *}$ \\
& $(2.731)$ & $(18.744)$ \\
\hline Number of observations & 112 & 112 \\
\hline $\mathrm{R}^{2}$ & 0.218 & 0.242 \\
\hline Adjusted $\mathrm{R}^{2}$ & 0.056 & 0.086 \\
\hline F statistic $(\mathrm{df}=4 ; 92)$ & $6.395^{* * *}$ & $7.359^{* * *}$ \\
\hline
\end{tabular}

Note: Values in parentheses indicate standard errors.

$G D P=$ gross domestic product.

${ }^{*} p<0.1 ;{ }^{* *} p<0.05 ;{ }^{* * *} p<0.01$.

Source: Prepared by the authors.

The GDP variable, which indicates the growth in GDP, is the only one that has a high level of significance, and may therefore explain profitability for both dependent variables, ROA and ROE.

Based on the information of the $F$ statistic, it is possible to say that the model is significant, as the $p$ value is approximately equal to zero.

According to the results of Table 11, no relationship was found between the competition (a characteristic of conduct) and profitability (a characteristic of performance) variables.
A higher interest rate and spread are perceived as consequences of an environment with little competition, which would enable higher profitability for banks. Although Brazil has profitability indices that are consistent with the standard for the continent, with a lower ROA than the mean for Latin America and ROE in line with the mean, Brazil has extremely high spread and interest rate levels, considered the highest in the world, and inconsistent with its peers in Latin America, as observed in Table 12.

Table 12

Bank spread and bank credit interest rate for the private sector

\begin{tabular}{ccc}
\hline & Bank spread & $\begin{array}{c}\text { Interest rate } \\
(\mathbf{\%})\end{array}$ \\
\hline Brazil & 39.37 & 52.10 \\
\hline Paraguay & 14.32 & 31.23 \\
\hline Peru & 13.82 & 16.47 \\
\hline Guyana & 11.83 & 13.00 \\
\hline Uruguay & 9.62 & 16.17 \\
\hline Colombia & 7.53 & 14.65 \\
\hline Argentina & 6.95 & 31.23 \\
\hline Bolivia & 6.51 & 7.95 \\
\hline Venezuela & 5.69 & 20.77 \\
\hline Surinam & 5.6 & 13.48 \\
\hline Chile & 1.63 & 5.59 \\
\hline
\end{tabular}

Source: International Monetary Fund (2018) and World Bank (2018).

In a study of the Central Bank of Brazil (2018), in which a breakdown was made of the Brazilian bank spread, it was found that profit margin represents from $20 \%$ to $30 \%$ by the spread. Thus, a strong competitive environment, in which there is a reduction in profit margins, is not a sufficient condition for a reduction in the spread and interest rates in Brazil. 


\section{CONCLUSION}

Using a sample of 16 countries in Latin America, covering the period from 2011 to 2017, this study sought to test the hypotheses of Bain's (1951) SCP model, which states that concentration (structure) reduces competition (conduct), causing higher profitability (a measure of performance) in the sector.

Bank competition was measured by Panzar and Rosse's (1987) model, which proposes estimating the elasticities of a bank's revenue to variations in fundraising, workforce, and capital prices, which are considered bank inputs. It was verified, through POLS estimation, that Brazil presents a competition index of 0.49 , the lowest of the countries studied. Chile and Uruguay, in turn, present numbers above 0.80 , which is considered high, indicating greater competition in the banking market. Although they diverge in the values measured, all the economies of the region are characterized as having a market with monopolistic competition, as they are within the interval between 0 and 1 .

Concentration was measured by the $\mathrm{HHI}$ and $\mathrm{CR}_{5}$ indices, calculated based on the banks' total assets. It was verified that, for 2017, Mexico is the country with the lowest concentration in the sample, with 871.88 points, while Panama presents the highest concentration level, with 2,399.57. Brazil, the biggest economy in the region, has an HHI of 1,187, lower than the mean for the region.

The characteristics of performance, measured by the ROA and ROE indices, indicated that the markets of Argentina, Paraguay, and Peru have high profitability, while Costa Rica, Ecuador, and Uruguay have the lowest indices in the region.

Finally, the regressions to verify the link between competition and concentration find no statistically significant relationship between the variables, in line with the research of Jansen and de Haan (2003) and, therefore, opposed to that of Bikker and Groeneveld (2000), both carried out with European banks. For competition and profitability, no significant relationship was found between the variables either, which is also in line with the research of Jansen and de Haan (2003).

According to Febraban (2018), in the debate in Brazilian society, some attribute the high spreads practiced in the country to the concentration in the banking sector: "It is argued that concentration inhibits competition, which would lead to abusive profits, largely derived from the high spreads" (p.40), which can be contested through statistics in this study.

Therefore, this study contributes to the literature regarding banks' market power and profitability, widening the debate using empirical evidence.

\section{REFERENCES}

Allen, F., \& Gale, D. (2004). Competition and financial stability. Journal of Money, Credit and Banking, 36(3), 453-480.

Bain, J. S. (1951). Relation of profit rate to industry concentration: American manufacturing, 1936-1940. Quarterly Journal of Economics, 65(3), 293-324.

Banco Central do Brasil. (2018). Relatório de economia bancária.

Barbosa, K., Rocha, B., \& Salazar, F. (2015). Assessing competition in the banking industry: A multi-product approach. Journal of Banking \& Finance, 50(2015), 340-362.

Berger, A. N. (1995). The profit - structure relationship in banking: Tests of market power and efficient-structure hypotheses. Journal of Money, Credit, and Banking, 27, 404431.

Berger, A. N., \& Hannan T. H. (1989). The price-concentration relationship in banking. Review of Economics and Statistics 71(2), 291-299.

Berger, A. N., \& Mester, L. (2003). Explaining the dramatic changes in performance of US banks: Technological change, deregulation, and dynamic changes in competition. Journal of Financial Intermediation, 12(1), 57-95.
Berger, A., Molyneux P., \& Wilson J. (2015). The Oxford handbook of banking. Oxford University Press.

Berstain, S., \& Fuentes, R. (2005). Concentration and price rigidity: Evidence from the deposit market in Chile [Working Paper]. Central Bank of Chile.

Bertrand, J. (1883). Book review of theorie mathematique de la richesse sociale and of recherches sur les principles mathematiques de la theorie des richessesí. Journal de Savants, 67, 499-508.

Bikker, J. A., \& Groeneveld H. J. (2000). Competition and concentration in the EU banking industry. Kredit und Kapital, 33(1), 62-98.

Bikker, J. A., \& Haaf K. (2002). Competition, concentration and their relationship: An empirical analysis of the banking industry. Journal of Banking and Finance, 26(1), 2191-2214.

Bresnahan, T. (1982). The oligopoly solution concept is identified. Economics Letters, 10(1), 87-92.

Bresnahan, T., \& Reiss, P. (1991). Entry and competition in concentrated markets. Journal of Political Economy, 99(5), 977-1009. 
Calomiris, C. W., \& Kahn, C. M. (1991). The role of demandable debt in structuring optimal banking arrangements. American Economic Review 81(3), 497-513.

Casu, B., \& Girardone, C. (2006). Bank competition, concentration and efficiency in the single European market. The Manchester School, 74(4), 441-468.

Cetorelli, N., \& Gambera, M. (2001). Banking structure, financial dependence and growth: International evidence from industry data. Journal of Finance 56(2), 617-648.

Claessens, S., \& Laeven, L. (2004). What drives bank competition? Some international evidence. Journal of Money, Credit, and Banking, 36(3), 563-584.

Claessens, S., \& Laeven, L. (2005). Financial dependence, banking sector competition, and economic growth. Journal of the European Economic Association 3(1), 179-207.

Claessens, S., Demirgüc-Kunt, A., \& Huizinga, H. (2001). How does foreign entry affect domestic banking markets? Journal of Banking and Finance, 25(5), 891-911.

Coccorese, P. (2004). Banking competition and macroeconomic conditions: A disaggregate analysis. Journal of International Financial Markets, Institutions and Money, 14(3), 203-219.

Coelho, C., Mello, J., \& Rezende, L. (2013). Do public banks compete with private banks? Evidence from concentrated local markets in Brazil. Journal of Money, Credit, and Banking, 45(8), 1581-1615.

Cull, R., Martinez-Peria, M. S., \& Verrier, J. (2017). Bank ownership: Trends and implications [Working Paper]. International Monetary Fund.

De Bandt, O., \& Davis, P. (2000). Competition, contestability and market structure in European banking sectors on the eve of EMU. Journal of Banking and Finance, 24(6), 1045-1066.

Degryse, H., Kim, M., \& Ongena, S. (2009). Microeconometrics of banking: Methods, applications, and results. Oxford University Press.

Diamond, D. W. (1984). Financial intermediation and delegated monitoring, Review of Economics Studies, 51(3), 393-414.

Diamond, D. W., \& Rajan, R. G. (2001). Liquidity risk, liquidity creation, and financial fragility: A theory of banking. Journal of Political Economy, 109(2), 287-327.

Fama, E. F. (1985). What's different about banks? Journal of Monetary Economics, 15(1), 29-39.

Fase, M., \& Abma, R. (2003). Financial environment and economic growth in selected Asian countries. Journal of Asian Economics, 14(1), 11-21.

Fazio, D., Tabak, B., \& Cajueiro, D. (2013). Systemically important banks and financial stability: The case of Latin America. Journal of Banking \& Finance, 37(10), 3855-3866.

Federação Brasileira de Bancos. (2018). Como fazer os juros serem mais baixos no Brasil - Uma proposta dos bancos ao governo, Congresso, Judiciário e à sociedade.

Federación Latinoamericana de Bancos. (November $17^{\text {th }}, 2018$ ). Informacion macroeconômica y bancaria de America Latina. https://indicadores.felaban.net/indicadores_homologados/ indicador.php

Freixas, X., \& Rochet, J.-C. (1997). Microeconomics of banking. The MIT Press.
Guerrero, R., Sepulveda, E., \& Villalpando, M. (2005). Profitability, concentration and efficiency in the Mexican banking industry. Presented at the Latin American and Caribbean Economic Association Annual Conference, Paris, France.

Hawkins, J., \& Mihaljek, D. (2001). The banking industry in the emerging market economies: Competition, consolidation and systemic stability - An overview. BIS Papers, 4, 1-43.

Hellman, T., Mudock, K., \& Stiglitz, J. E. (2000). Liberalization, moral hazard in banking and prudential regulation: Are capital controls enough? American Economic Review, 90(1):147-165.

Holmstrom, B., \& Tirole, J. (1998). Public and private supply of liquidity. Journal of Political Economy, 106(1), 1-40.

International Monetary Fund. (November $17^{\text {th }}, 2018$ ). Monetary \& financial statistics (MFS). https://data.imf.org/?sk=B83F71E861E3-4CF1-8CF3-6D7FE04D0930

Jansen, D., \& de Haan, J. (2003). Increasing concentration in European banking: A macro-level analysis. Netherlands Central Bank.

Khan, M. S., \& Senhadji, A. S. (2000). Financial development and economic growth: An overview [Working Paper]. International Monetary Fund.

Lau, L. J. (1982). On identifying the degree of competitiveness from industry price and output data. Economics Letters, 10(1), 93-99.

Levine, R. (2003). Bank-based or market-based financial systems: Which is better? Journal of Financial Intermediation, 11(4), 398-428.

Martins, T., Bortoluzzo, A., \& Lazzarini, S. (2014). Competição bancária: Comparação dos comportamentos de bancos públicos e privados. Revista de Administração Contemporânea, 18(1), 86-108.

Matthews, K., Murinde, V., Zhao, T., (2007). Competitive conditions among the major British banks. Journal of Banking and Finance, 31, 2025-2042.

Matthews, K., \& Thompson J. (2014). The economics of banking. Wiley.

Molyneux, P., Lloyd-Williams, D. M., \& Thornton, J. (1994). Competitive conditions in European banking. Journal of Banking and Finance, 18(3), 445-459.

Molyneux, P., Lloyd-Williams, D. M., \& Thornton, J. (1996). Competition and market contestability in Japanese commercial banking. Journal of Economics and Business, 48(1), 33-45.

Nakane, M. (2001). A test of competition in Brazilian banking [Working Paper]. Banco Central do Brasil.

Nathan, A., \& Neave, E. H. (1989). Competition and contestability in Canada's financial system: Empirical results. Canadian Journal of Economics, 22(3), 576-594.

Panzar, J. C., \& Rosse, J. N. (1987). Testing for monopoly equilibrium. Journal of Industrial Economics, 35(4), 443456.

Peria M. S. M., \& Moky, A. (2004). How foreign participation and market concentration impact bank spreads: Evidence from Latin America. Journal of Money, Credit and Banking, 36(3), 511-537. 
Rajan, R. G., \& Zingales, L. (1998). Financial dependence and growth. American Economic Review, 88(3), 559-586.

Rime, B. (1999). Mésure du degré de concurrence dans le système bancaire suisse à l'aide du modèle de Panzar et Rosse. Swiss Journal of Economics and Statistics, 135(1), 21-40.

Rosse, J. N., \& Panzar J. C. (1977). Chamberlin vs. Robinson: An empirical test for monopoly rents [Discussion Paper]. Bell Laboratory Economics/Stanford University.

Shaffer, S. (1982). Competition, conduct and demand elasticity. Economic Letters, 10(1-2), 167-171.

Shaffer, S. (1989). Competition in the U.S. banking industry. Economics Letters 29(4), 321-323.

Singh, A., Belaisch, A., Collyns, C., De Masi, P., Krieger, R., Meredith, G., \& Rennhack, R. (2005). Stabilization and reform in Latin America: A macroeconomic perspective of the experience since the 1990s [Occasional Paper]. International Monetary Fund.

Smirlock, M. (1985). Evidence on the (non) relationship between concentration and profitability in banking. Journal of Money, Credit, and Banking, 17(1), 69-83.
Sun, Y. (2011). Recent developments in European bank competition. IMF working paper WP/11/146.

The United States Department of Justice. (2010). Horizontal merger guidelines. https://www.justice.gov/atr/horizontalmerger-guidelines-08192010\#5c

UOL. (January $18^{\text {th }}, 2020$ ). América Latina compensa resultado fraco do Santander na Europa. https://economia.uol.com.br/ noticias/bloomberg/2019/07/23/america-latina-compensaresultado-fraco-do-santander-na-europa.htm

Vesala, J. (1995). Testing competition in banking: Behavioral evidence from Finland. Bank of Finland Studies.

World Bank. (November $17^{\text {th }}, 2018$ ). DataBank - Global financial development. https://datacatalog.worldbank.org/dataset/ global-financial-development

Yeyati, E. L., \& Micco, A. (2007). Concentration and foreign penetration in Latin American banking sectors: Impact on competition and risk. Journal of Banking and Finance, 31, 1633- 1647.

Yildirim, H., \& Philippatos, G. (2007). Restructuring, consolidation and competition in Latin American banking markets. Journal of Banking and Finance, 31(3), 629-639. 